\title{
WSPOMNIENIE O PROFESORZE BOGUSŁAWIE NOWOWIEJSKIM (1954-2019) Z OKAZJI PIERWSZEJ ROCZNICY ŚMIERCI
}

26 września 2019 roku zmarł Profesor Bogusław Nowowiejski - wybitny językoznawca, nauczyciel wielu pokoleń studentów białostockiej polonistyki, dla wielu z nas nieodżałowany kolega, współpracownik, nauczyciel.

Był jednym z najbardziej rozpoznawalnych w kraju reprezentantów środowiska naukowego Uniwersytetu w Białymstoku. Współtworzył Instytut Filologii Polskiej, był jego wicedyrektorem (w latach 1985-1999) i przewodniczącym Rady Naukowej (od 2005 do 2008 roku). Jako dziekan Wydziału Filologicznego (w latach 2008-2016 roku), kierownik Zakładu Historii Języka Polskiego oraz promotor wielu prac dyplomowych, magisterskich i doktorskich, miał znaczący wpływ na kształtowanie kadry naukowej wydziału, zwłaszcza środowiska językoznawczego. Do ostatniego niemal dnia był zaangażowany w redagowanie periodyku „Białostockie Archiwum Językowe", na którego łamach debiutowało wielu młodych badaczy. Pan Profesor był ich przewodnikiem jako niedościgły mistrz stylu naukowego, wymagający, lecz zawsze życzliwy i pomocny. Niesłabnące $\mathrm{z}$ wiekiem zainteresowanie dokonaniami koleżanek i kolegów znalazło wyraz w imponującej aktywności recenzenckiej Pana Profesora. Jego własne prace - książki i niezliczone artykuły - świadczą o rozległości zainteresowań obejmujących historię języka polskiego, dialektologię, socjolingwistykę i onomastykę. Najważniejsze monografie: „Zapożyczenia leksykalne z języka niemieckiego w polszczyźnie XIX wieku” (1996) oraz „Niemiecko-polski słownik Mrongowiusza: źródło do historii polskiej leksyki i leksykografii” (2011) stworzyły metodologiczną podstawę 
do badań nad polsko-niemieckimi kontaktami językowymi. W dorobku Bogusława Nowowiejskiego znalazły się także znakomite studia nad gwarami Podlasia i kresów północno-wschodnich, m.in. nad dziewiętnastowiecznymi słowniczkami gwarowymi, w których opracowanie włączyli się najzdolniejsi uczniowie i współpracownicy Pana Profesora - godni kontynuatorzy Jego prac.

Profesor Bogusław Nowowiejski był lokalnym patriotą, zaangażowanym w życie miasta, regionu i naszej uczelni. Jego osobowość: pogoda ducha, bezpośredniość, życzliwość, jak również talent organizacyjny i dydaktyczny sprawiały, że cieszył się powszechną sympatią i szacunkiem. Ze smutkiem przyjęliśmy przed rokiem wiadomość o Jego przedwczesnym odejściu. Osobę i dorobek naukowy Pana Profesora zachowamy we wdzięcznej pamięci.

Irena Szczepankowska

Uniwersytet w Białymstoku i.szczepankowska@uwb.edu.pl http://orcid.org/0000-0003-1056-606X 